The successor to the journal Music Review, Nineteenth-Century Music Review aims to locate music within the widest possible framework of intellectual activity pertaining to the long nineteenth century (c.1789-1914). It particularly welcomes interdisciplinary scholarship that explores music within the context of other artistic and scientific discourses. Articles with fine visual or iconographic content are encouraged, as are those rich in musically illustrative material. Articles accepted for publication will reflect a diversity of critical viewpoints.

\title{
Contents of Volume 5, Issue 1
}

Articles

John Spitzer

Denise Yim

Andrew Cyprian Love

Kevin O'Regan

Book Reviews

CD Review Article

Simon Trezise

Elgar's Recordings

CD Reviews

The Entrepreneur-conductors and their Orchestras

A British Child's Music Education, 1801-1810: G.B. Viotti, Caroline Chinnery and the French Influence

Process and Product in Theology and Musical Aesthetics: Improvisation as Interdisciplinary Topos

Wackenroder and the Doctrine of the Soul

Score Reviews 